\title{
IAMJ
}

INTERNATIONAL

AYURVEDIC

MEDICAL JOURNAL

ISSN: 23205091

Impact Factor: 5.344

\section{A COMPARATIVE CLINICAL STUDY TO EVALUATE THE EFFICACY OF DARVYADI LEHYA AND DRAKSHADI LEHYA IN PANDU ROGA W.S.R TO I.D.A}

\author{
Karthika Raj ${ }^{1}$, Susheel Shetty ${ }^{2}$ \\ ${ }^{1} 3^{\text {rd }}$ year PG scholar (Dept. of Kayachikitsa), Alva's Ayurveda Medical College and Hospital, Moodbidri, \\ Karnataka, India \\ ${ }^{2}$ Professor, (Dept of PG Studies in Kayachikitsa), Alva's Ayurveda Medical College and Hospital, Moodbidri, \\ Karnataka, India
}

Corresponding Author: drkarthikaraj9110@gmail.com

https://doi.org/10.46607/iamj0408092020

(Published online: September 2020)

Open Access

(C) International Ayurvedic Medical Journal, India 2020

Article Received:17/07/2020 - Peer Reviewed:04/08/2020 - Accepted for Publication:08/09/2020

(D) Check for updates

\begin{abstract}
Pandu is a Pitta Pradhana Tridoshaja Vikara affecting the Rasavaha srotas causing Sapta Dhatu Kshaya and Ojokshayal. The disease is characterized by Panduvamata and Arohana Ayasa. Karnakshweda, Agnimandya, Daurbalya, Annadwesha, Srama, Bhrama, Gathrashoola, Arohanaayasa, Aruchi, Gaurava etc. are the other symptoms commonly found in the patients of Pandu. In the Present era, Anaemia is a burning issue around the world and W.H.O Global data base 2011 reveals that, in a 120 million population, $83 \%$ people are suffering from anaemia ${ }^{2}$.Present study was conducted on 60 diagnosed patients of Panduwho were randomly allocated with 30 each in two groups. Darvyadhi Lehya was given for one group and Drakshadhi Lehya a widely used formulation in clinical practice was given for another group. The study was conducted in 60 subjects for a period of 30 days. Clinical features and haematological parameters were documented before and after the treatment. The results of the study showed that, a statistically significant difference was not seen between the effect of Darvyadi and Drakshadilehya in Pandu roga.
\end{abstract}


Keywords: DrakshadhiLehya, DarvyadhiLehya, Pandu Roga, Anaemia.

\section{INTRODUCTION}

In Ayurveda, Panduroga is a considered as an independent disease with its own specific Nidana, Purvarupa, Rupa, Samprapti and Chikitsa. Acharya Charaka has mentioned Rakthalpatha in Pandu Roga ${ }^{3}$. So, Pandu Roga can be compared to Anaemia. Anaemia is a condition in which $\mathrm{Hb} \%$ becomes lower than the normal. In the Present era, Anaemia is a burning issue around the world, it affects all age groups but the most vulnerable are preschool age children, pregnant women and non pregnant woman of child bearing age $^{4}$. Globally anaemia affects 1.62 billion people which correspond to $24.8 \%$ of the population. The highest prevalence of anaemia exists in the developing world, where its causes are multifactorial $^{3}$. Two Lehya yogas have been selected here since according to Ayurveda Pandu is a Pitta Pradhana Tridoshaja Vikara affecting the Rasavahasrotas causing Saptha dhatukshaya and ojokshaya. In Pandu roga the ushna guna increases, the pitta is further vitiated causing kshapana of rasa prasada bhaga, which does poshana of Raktha dhatu. This induces rokshya bhava in the individual. As rasa dhatu is Sneha pradhana, Sneha would be an apt choice here which would bring about the increase of uttarothra saptha dhatus $^{5}$.

\section{Materials and Methods}

\section{Source Of Data :-}

- Drug Source:- From the source of procurement.

- Drug Preparation:- Dept of Rasashastra and Bhaishajya Kalpana, Alva's Ayurveda Medical College, Moodbidri.

Sample Source:- OPD and IPD of PG studies of Kayachikitsa, Alva's Ayurveda Medical College Hospital, Moodbidri.

\section{Method of Data Collection:-}

a) Selection of patients:- Irrespective of gender, religion, occupation, marital status, socio-economic status and education status.

- Sample size :- 60 participants

- Grouping :- 2 arms ( A and B )

- Number:- 30 in each arm.
- Study design:- Randomized controlled clinical study.

- Blinding :- Single blind

- Method Of Sampling:- Lottery method.

b) Diagnostic criteria :-

1. Panduta and Arohana Ayasa with or without other Lakshanas of Pandu Roga.

2. Haemoglobin percentage between $8-12 \mathrm{gm} \%$ in Males and 7-11gm\% in Females.

3. Microcytic or Normocytic, Hypochromic RBCs in blood smear picture.

c) Inclusion Criteria :-

1. Patients between 16-60 years of age.

2. Patients having Pratyatma Lakshanas of Pandu Roga - Panduta and Arohana Ayasa with or without other Lakshanas of the disease.

3. Haemoglobin percentage between $8-12 \mathrm{gm} \%$ in Males and 7-11gm\% in Females.

4. Blood picture presenting with either microcytic hypochromic or normocytic hypochromic anaemia.

\section{d)Exclusion Criteria: -}

Patients who do not give consent for treatment.

- Patients suffering from infectious diseases.

- Pandu Roga resulting from acute or chronic blood loss.

- Patients with systemic disorders that would interfere with the course of the study.

- All types of secondary, congenital, hereditary anaemia.

- Pregnant and lactating mothers are excluded.

\section{e) Intervention:-}

Group A: Drakshadi Lehya 10gm before food, twice a day for 30 days, Anupana: Ushnodhaka

Group B: Darvyadi Lehya 10gm before food, twice a day for 30 days, Anupana: Ushnodhaka

\section{f) Observation Period:-}

Patients will be assessed for the clinical parameters before treatment, on $16^{\text {th }}$ day and after treatment. Laboratory parameters will be assessed before 
treatment and on $31^{\text {st }}$ day after treatment.

g) Assessment Criteria: Subjective (Clinical)

1. Panduta

2. Arohana Ayasa

Objective (Laboratory)

$\mathrm{Hb} \%$; RBC Count; PCV; Blood Picture; MCV

h) Statistical Methods

Assessment of the condition will be done based on detailed proforma adopting standard scoring methods of subjective and objective parameters and will be analysed using student ' $t$ ' test.

\section{Observation \& Result}

Observation

In the present study highest incidence $(51.6 \%)$ was in the age group of $16-25 \mathrm{yrs}$ and the lowest incidence $(5 \%)$ was in the age group of 46-55years. Which represents the onset was more in youth and middle aged. According to gender Panduroga was highest $(78.3 \%)$ in females and lowest in Males (21.6\%). According to Menstrual History Regular periods were observed in $63.8 \%$,irregular periods were observed in 29.78\%, Menopause was observed in $6.38 \%$ patients. However, women with normal menstruation, if don't take sufficient Iron containing foods may develop IDA. Anaemia also leads to the deterioration of general health leading to leucorrhoea ${ }^{6}$. In Diet observed that $91.6 \%$ patients were having mixed diet and 8.3\%patients were consuming veg diet. According to Dietic habits, it was observed that most of the people followed Vishamashana 40\%, Adhyashana was $31.6 \%$, Anashana 20\% and Samashana 8.3\%. Vishamashana and Adhyashana causes Agnimandya which later leads to Dhatwagnimandya which leads to Dhatushaithilya or dushti which causes Doshaprakopa which is the root cause of disease $^{7}$. Anashana causes agni vriddi which effects the dhatus, thus could indirectly be a reason for Raktalpatha causing Pandu Roga. According to Rasa in Diet Katu pradhana ahara was taken more frequently by about $71.6 \%$, Madhuraaharas $61.6 \%$, Amla aharas $36.6 \%$, Lavanaaharas $28.3 \%$ and Tikta, kashaya rasas were least taken that is
13.3\%. Katu, Amla and Lavana Rasa have already indicated as Nidanas of Pandu Roga and they directly vitiate Pitta and Rakta and lead to Dushana of Raktha, Causes Shaithilya in Dhatu. In Agni, it was observed that Mandagni was present in highest incidence 35\%, Samagni 26.6\%, Vishamagni $23.3 \%$ and Tikshnagni was least in number $15 \%$.Most of the patients had Mandagni. Pandu is also an agnimandya vikara. According to Shareera Prakriti The deha prakruti of the patients were also assessed, after considering their major physical, psychological and behavioural features. It was observed that Vatakapha 38.3\%, Vatapitta 46.6\%, Kaphapitta 10\%, Pittakapha 5\% patients were observed while assessing the Prakriti. So, along with the assessment of prakriti consumption of Nidana as per classics could have lead to causation of Pandu Roga in the person ${ }^{9}$. In Vyayama Shakthi, most people showed Madhyama Vyayama Shakthi that is $86.6 \%$, Avara $10 \%$ only a little percentage showed Pravara Vyayama Shakthi of $3.3 \%$. This is noted by the cardinal features 'Arohanaayasa' seen in all patients suffering from Pandu roga $a^{10}$. Among the varieties of pandu most belonged to the group of Vataja Pandu that is about 50\%, Kaphaja Pandu is about 35\%, Pittaja Pandu is about $15 \%$ and Sannipataja Pandu is nil. This was assessed purely on the Lakshanas.

\section{Results}

Table 1: Statistical Result of Individual Assessment Criteria

Table2: Overall Relief Observed in Patients Of Group A And B

\section{DISCUSSION}

In this study, we have seen $74.200 \%$ and $83.61 \%$ of relief of Panduta in Group A and Group B respectively. The results were found to be highly significant in two groups that is $\mathrm{p}<0.001$. And in this study we have seen $76.50 \%$ and $78.82 \%$ of relief of ArohanaAyasa in Group A and Group $B$ respectively. The results were found to be 
highly significant in two groups that is $\mathrm{p}<0.001$.

Laboratory Parameters: Among the laboratory parameters, maximum increase in $\mathrm{Hb}$ was recorded in two female patients of Group B. The $\mathrm{Hb}$ before treatment $9.7 \mathrm{gm} \%$ and after treatment was 12. There was an increase of $2.3 \mathrm{gm} \%$.Rest of the values falls in range between $\quad 0.3 \mathrm{gm} \%$ and $1.8 \mathrm{gm} \%$. Statistical significance of $\mathrm{Hb}, \mathrm{PCV}, \mathrm{MCV}$ was $\mathrm{p}<0.001$, except for Blood picture and $\mathrm{RBC}$ that was obtained as $\mathrm{p}=0.001$ and $\mathrm{p}=0.103$.

In Group A 3 patients had showed an $\mathrm{Hb}$ of $9 \mathrm{gm} \%$ which after treatment had increased by 2 units. Rest of the values fell in between $0.4 \mathrm{gm} \%$ and $1.7 \mathrm{gm} \%$. In Group A statistical significance was seen in $\mathrm{Hb}, \mathrm{PCV}, \mathrm{MCV}, \mathrm{RBC}$, Blood picture, to be $\mathrm{p}<0.001$.

In both group blood picture has not shown highly significant result, since the period of consumption of drug that is 30 days is not sufficient for producing changes in the structure of RBC. But finally depending upon all other variables, both Drakshadi and DarvyadiLehya were effective in treatment of Pandu Roga and statistical difference in treatment effect were seen between the two.

Discussion on the result of treatment in Group A and Group B: Drakshadilehya and Darvyadilehya after treatment showed statistically significant result. By the $16^{\text {th }}$ day itself clinical parameters had responded, though the lab parameters were only done on $31^{\text {st }}$ day for assessment.

Discussion on the comparative effects of treatment in Group A and Group B :

The result obtained after treatment in both groups was compared by Unpaired t test. The test revealed that there is no significant difference between the effect of treatment in both groups.

Overall Group wise relief on $31^{\text {st }}$ day of treatment: Marked relief was observed in 12 patients in Group A and 13 patients were found with Marked improvement in Group B. Moderate relief was observed in 18 patients in Group A and 17 patients were found with
Moderate improvement in Group B.

Adverse Effects: There was no adverse effects were noted during the treatment.

\section{CONCLUSION}

In Ayurveda, Pandu roga is a considered as an independent disease with its own specific Nidana, Purvarupa, Rupa, Samprapti and Chikitsa.In the present clinical trial, Group A and Group B result shows that the effect of both treatment produced highly significant results for subjective parameter like Pandutha and Arohanaayasa as well as for objective criteria like $\mathrm{Hb} \%$. Blood picture, PCV, MCV and RBC. The clinical results and laboratory results obtained, were found to be statistically significant at $p<0.001$ except for RBC and Blood picture in Group B, were $p$ value was greater than 0.05 , since it's difficult to have changes in blood picture in duration of 30days. Hence the conclusion drawn was, there was there was no significant difference in the effect of Darvyadi and Drakshadilehya in Pandu roga.

\section{REFERENCES}

1. Acharya Agnivesh, Charaka Samhita, commentary Chakrapani Dutta, edited by JadavjiTrikamji Acharya, Edition, reprint 2009, Choukambha publication, Chikitsa Sthana 16/6, P. 233

2. John. W. Adamson et al Harrison's Principle of Internal Medicine, Hematopoietic Disorders, Section2, The Mc Graw Hill Companies, 2005, USA, $16^{\text {th }}$ edition, Vol 1, P.586.

3. www.who.int/WHO/Globalanaemia prevalence and number of individuals affected.

4. Acharya Vagbhata: Astangahridaya, Varanasi, Chaukambha Sanskrit sansthana, reprint 2004,Sutrasthana Chapter16,Shloka No-2 .

5. https://books.google.co.in/books? ISBN=1550093614, Nutrition in Pediatrics: Basic Science: Clinical Application.

6. Agnivesha: Charakasamhita elaborated by Charaka\& redacted Dridabala, with Ayurveda Dipika commentary by Chakrapanidatta, Acharya Yadavji Trikamji editor, 2009, Varanasi, and Chaukhamba Orientalia, Sutrasthana, Chapter-26

7. Shiva kumar Gowda, Ayurvediya Shareera Kriya 
Vijian, Nath PusthakBhandar, Harayana, First Edition-1973, Chapter- 6, Page.No-42,48.

8. https://books.google.co.in/books?isbn=8131243710,P harmacology \& Pharmacotherapeutics E books

9. Shiva kumar Gowda, Ayurvediya Shareera Kriya Vijian, Nath Pusthak Bhandar, Harayana, First
Edition-1973, Chapter- 6, Page.No-42,48.

10. Agnivesha: Charakasamhita elaborated by Charaka \& redacted Dridabala, with Ayurveda Dipika commentary by Chakrapanidatta, Acharya Yadavji Trikamji editor, 2009, Varanasi, and Chaukhamba Orientalia, Sutrasthana, Chapter-26

Table 1: Statistical Result of Individual Assessment Criteria

\begin{tabular}{|c|c|c|c|c|c|c|c|c|c|}
\hline $\begin{array}{l}\text { Assessment } \\
\text { Criteria }\end{array}$ & Group & $\begin{array}{l}\text { BT } \\
\text { mean }\end{array}$ & $\begin{array}{l}\text { AT } \\
\text { mean }\end{array}$ & M.D & $\%$ & S.D & S.E & t Value & $\begin{array}{l}\mathrm{p} \\
\text { Value }\end{array}$ \\
\hline \multirow[t]{2}{*}{ ArohanaAyasa } & A & 1.833 & 0.433 & 0.433 & 76.50 & 0.621 & 0.113 & 12.339 & $<0.001$ \\
\hline & B & 1.700 & 0.367 & 0.367 & 78.82 & 0.479 & 0.0875 & 15.232 & $<0.001$ \\
\hline \multirow[t]{2}{*}{ Pandutha } & A & 1.667 & 0.433 & 0.433 & 74.20 & 0.568 & 0.104 & 11.886 & $<0.001$ \\
\hline & B & 1.633 & 0.267 & 0.267 & 83.61 & 0.490 & 0.0895 & 15.272 & $<0.001$ \\
\hline \multirow[t]{2}{*}{$\mathrm{Hb}$} & A & 10.520 & 11.672 & 11.672 & 10.93 & 0.674 & 0.123 & -9.358 & $<0.001$ \\
\hline & B & 9.980 & 11.397 & 11.397 & 14.12 & 0.680 & 0.124 & -11.419 & $<0.001$ \\
\hline \multirow[t]{2}{*}{ PCV } & A & 35.280 & 41.543 & 41.543 & 17.74 & 4.313 & 0.787 & -7.954 & $<0.001$ \\
\hline & B & 34.759 & 40.273 & 40.273 & 15.8 & 4.570 & 0.834 & -6.610 & $<0.001$ \\
\hline \multirow[t]{2}{*}{$\mathrm{MCV}$} & A & 69.300 & 74.813 & 74.813 & 7.95 & 3.008 & 0.549 & -10.041 & $<0.001$ \\
\hline & B & 69.093 & 73.687 & 73.687 & 6.64 & 3.508 & 0.641 & -7.172 & $<0.001$ \\
\hline \multirow[t]{2}{*}{ Blood picture } & A & 1.700 & 1.100 & 1.100 & 35.29 & 0.621 & 0.113 & 5.288 & $<0.001$ \\
\hline & B & 1.233 & 0.933 & 0.933 & 24.39 & 0.466 & 0.0851 & 3.525 & $=0.001$ \\
\hline \multirow[t]{2}{*}{$\mathrm{RBC}$} & A & 4.596 & 5.437 & 5.437 & 18.3 & 0.404 & 0.0738 & -11.397 & $<0.001$ \\
\hline & B & 4.483 & 6.796 & 6.796 & 51.56 & 7.535 & 1.376 & -1.682 & $=0.103$ \\
\hline
\end{tabular}

Table 2: Overall Relief Observed In Patients Of Group A And B:

\begin{tabular}{|l|l|l|l|l|}
\hline Remarks & Group A & $\%$ & Group B & $\%$ \\
\hline Marked relief Above 75\% & 12 & 40 & 13 & 43.3 \\
\hline Moderate relief 50-74\% & 18 & 60 & 17 & 56.6 \\
\hline Mild relief 25-49\% & 0 & 0 & 0 & 0 \\
\hline No relief Below 24\% & 0 & 0 & 0 & 0 \\
\hline
\end{tabular}

\section{Source of Support: Nil \\ Conflict of Interest: None Declared}

How to cite this URL: Karthika Raj \& Susheel Shetty A Comparative Clinical Study To Evaluate The Efficacy Of Darvyadi Lehya And Drakshadi Lehya In Pandu Roga W.S.R To I.D.A. International Ayurvedic Medical Journal \{online\} 2020 \{cited September, 2020 \} Available from: http://www.iamj.in/posts/images/upload/4324 4328.pdf 